\title{
Soft Tissue Sarcoma TNM Finding v7
}

National Cancer Institute

\section{Source}

National Cancer Institute. Soft Tissue Sarcoma TNM Finding v7. NCI Thesaurus. Code C88449.

A finding about one or more characteristics of soft tissue sarcoma, following the rules of the TNM AJCC V7 classification system. Kaposi sarcoma, fibromatosis (desmoid tumor), and sarcoma arising from the dura mater, brain, parenchymatous organs, or hollow viscera are not included in this classification. (from AJCC 7th Ed.) 